STUDY ON MANUFACTURE OF SPRAY DRIED WOOD

APPLE (Feronia limonia) AND BAEL (Aegal marmelose)

FRUIT PULPS AND THEIR POSSIBLE

USES IN THE INDUSTRY

BY

R.M. DEDUNU DILOSHINI RATHNAYAKE

THESIS SUBMITTED TO THE

UNIVERSITY OF SRI JAYAWARDENEPURA

FOR THE AWARD OF THE DEGREE OF

MASTER OF SCIENCE

IN FOOD SCIENCE AND TECHNOLOGY ON

AUGUST 2006 


\section{DECLARATION}

The work on this thesis was carried out by me under the supervision of Prof: Arther Bamunuarachchi (coordinator / Food Science and Technology programs, University of Sri Jayewardenepura); and Mr T.D.W Siriwardene (Research offfcer / Head, Food Research Unit Gannoruwa). Report on this thesis has not been submitted in whole or in part to any University or any other institution for another degree/diploma.

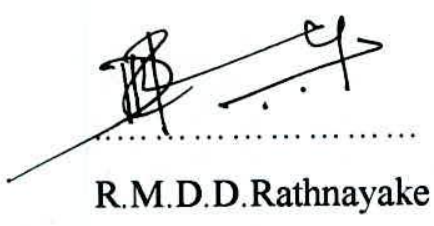


We certify that the above statement in the preceding page made by the candidate is true and that this thesis is suitable for submission to the University for the purpose of evaluation.

Supervisors,

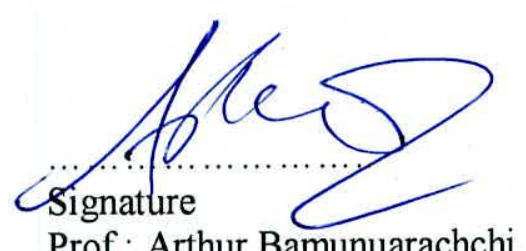

Prof; Arthur Bamunuarachchi, CO-ORDINATOR ,FOOD SCIENCE \& TECHNOLOGY PROGRAMMS, DEPARTMENT OF FOOD SCIENCE AND TECHNOLOGY, UNIVERSITY OF SRI JAYAWARDENEPURA, SRI LANKA.

\section{Signature}

Mr: T.D.W Siriwardene,

HEAD / RESEARCH OFFICER, FOOD RESEARCH UNIT, DEPARTMENT OF AGRICULTURE, PERADENIYA. 


\title{
A DEDICATION TO
}

\author{
RESPECT \\ MY \\ EVER LOVING \\ MOTHER \& FATHER
}




\section{CONTENTS}

LIST OF CONTENTS

Page

LIST OF FIGURES

I

LIST OF PLATES

V

VI

LIST OF TABLES

VII

FIGURES OF APPENDIX

VIII

PLATES OF APPENDIX

VIII

TABLES OF APPENDIX

VIII

LIST OF ABREVIATIONS

IX

ACKNOELEDGEMENTS

$\mathrm{X}$

ABSTRACT

XI

CHAPTER 1- INTRODUCTION

1.1 Introduction (General)

CHAPTER 2- LITERATURE REVIEW

2.1 An Overview of Wood Apple and Bael 3

2.1.1 Wood apple 3

2.1.1.1 Origin and Distribution 3

2.1.1.2 Varieties 3

2.1.1.3 Climate and Soil 3

2.1.1.4 Propagation 4

2.1.1.5 Season 4

2.1.1.6 Harvesting 4

2.1.1.7 Botanical Description 4

2.1.1.8 Chemical Composition 6

2.1.1.9 Medicinal Uses $\quad 6$

2.1.1.10 Food Uses

$\begin{array}{lll}2.1 .2 & \text { Bael } & 7\end{array}$ 
2.1.2.1 Origin and Distribution

2.1.2.2 Climate and Soil 8

2.1.2.3 Season 8

2.1.2.4 Harvesting 8

2.1.2.5 Varaeties 8

2.1.2.6 Botanical Description 9

2.1.2.7 Chemical Composition $\quad 11$

2.1.2.8 Medicinal Uses 11

2.1.2.9 Food Uses 11

2.2 Food Spoilage and Preservation $\quad 12$

2.3 Fruit Dehydration $\quad 13$

2.3.1 Advantages of Fruit Dehydration 13

2.3.2 Spray Drying 14

2.3.2.1 Technology of Spray dryer $\quad 15$

2.3.3 Factors affecting for high quality dried

Juice products 16

2.3.3.1 Quality of row material 16

2.3.3.2 Product temperature and time limit $\quad 16$

2.3.3.3 Additives 16

$\begin{array}{ll}2.4 \text { Pre processing operations } & 17\end{array}$

2.4.1 Harvesting 17

2.4.2 Selection and Preparation of fruit 17

2.4.3 Cleaning 17

2.4.4 Extraction of Juice $\quad 17$

2.4.5 Straining 18

$\begin{array}{ll}2.4 .6 \text { Homogenizing } & 18\end{array}$

2.5 Post Processing Operations 18

2.5.1 Packaging 18

2.6 Chemical and Physical Properties 19

2.6.1 Ascorbic acid (Vitamin C) 19

2.6.2 Water Activity 20 
2.6.2.1 Sorption Isotherm Studies 20

2.6.3 Solubility 21

2.6.4 Wettability 21

2.7 Sensory Evaluation $\quad 22$

2.7.1 The importance of the sensory analysis 23

2.7.2 Consumer Oriented Testing 23

2.7.2.1 Hedonic Test 23

\section{CHAPTER 3 -EXPERIMENTAL}

3.1 Preliminary trials 24

3.1.1 Determination of pulp to water ratio 24

3.1.1.1 Materials 24

3.1.1.2 Method 24

3.2 Product development Trials 25

3.2.1 Determination of pulp to maltodextrin ratio 25

3.3 Analysis of physical parameters 26

3.3.1 Determination of solubility 26

3.3.1.1 Materials 26

3.3.1.2 Method 26

3.3.2 Determination of bulk density 27

3.3.2.1 Materials 27

3.3.2.2 Method 27

3.3.2 Determination of Wettability 28

3.3.2.1 Materials 28

3.3.2.2 Method 28

3.4 Analysis of Chemical parameters 29

3.4.1 Determination of Moisture content 29

3.4.1.1 Materials 29

3.4.2.2 Method 29

3.4.2 Determination of Vitamin C 30

3.4.2.1 Materials 31

3.4.2.2 Method 31

3.4.3 Determination of Titratable Acidity 32 
3.4.3.1 Materials

3.4.3.2 Method

3.4.4 Determination of Ash content 33

3.4.4.1 Materials 33

3.4.4.2 Method 33

3.5 Moisture Sorption studies $\quad 34$

3.5.1 Materials $\quad 35$

3.5.2 Method 35

3.6 Sensory Evaluation $\quad 35$

3.6.1 Consumer oriented testing $\quad 35$

3.6.1.1Materials $\quad 35$

3.6.1.2 Method 36

\section{CHAPTER 4- RESULTS AND DISCUSIONS}

4.1 Preliminary trials 37

4.1.1 Determination of pulp to water ratio 37

4.2 Product development trials 38

4.3 Physical parameter studies $\quad 40$

4.4 Chemical composition studies $\quad 40$

4.5 Moisture sorption studies $\quad 42$

4.5.1 Moisture sorption isotherm $\quad 42$

4.5.2 BET monolayer plot $\quad 44$

4.5.3 Sorption Energy $\quad 47$

4.6 Sensory Evaluation $\quad 48$

4.6.1 Hedonic Testing $\quad 48$

4.6.1.1 Results of bael fruit drink powder $\quad 48$

4.6.1.2 Results of Wood apple fruit drink powder 49

4.7 Conclusions $\quad 52$

4.8 Suggestions for Further works 53

REFERANCES $\quad 54$

$\begin{array}{ll}\text { APPENDIX } & 57\end{array}$ 


\section{LIST OF FIGURES}

\section{Page}

Figure 1 - Botanical description of wood apple 5

Figure 2 - Botanical description of bael 10

Figure 3 - Idealized water sorption isotherm of a food system 20

Figure 4 - Moisture sorption behavior of wood apple powder 42

Figure 5 - Moisture sorption behavior of bael powder 43

Figure 6 - BET Monolayer plot for wood apple powder 45

Figure 7 - BET Monolayer plot for bael powder 46 


\section{LIST OF PLATES}

Page

Plate 1 - Wood apple powder incorporated with maltodextrin 39

Plate 2 - Bael powder incorporated with maltodextrin 39

Plate 3 - Comparison of wood apple powder and fresh drinks 50

Plate 4 - Comparison of bael powder and fresh drinks 50 


\section{FIGURES OF APPENDIX}

\section{PLATES OF APPENDIX}

Plate 5 - Wood apple (feronia limonia) 57

Plate 6 - Bael (Aegal marmelos) $\quad 57$

Plate 7 - Spray dryer (Model L8) $\quad 58$

Plate 8 - Processing $\quad 58$

\section{TABLES OF APPENDIX}

Table 19:- Results of Hedonic Analysis for bael (Aegal mamelose) 61

Table 20:- Results of Hedonic Analysis for wood apple (Feronia limonia) 64 


\section{LIST OF ABBREVIATIONS}

1. AA - Ascorbic Acid

2. MPA - Meta Phosphoric Acid

3. 2,6-DCP -2.6-Dichlorophenol indophenol

4. Sec. - Seconds

5. Mins. - Minutes

6. Fig. - Figure

7. App. - Appendix 


\subsection{Introduction}

The main objective of fruit processing is to supply wholesome, safe, nutritious and acceptable food to consumers and to minimize the post harvest losses. Development of processing, storage, transportation and marketing programs are very important to make efficient use of fruits and other farm products. Fruit processing projects also aim to replace imported products like squash, cordials, jams, syrups, beverages, pickles, etc.

Wood apple and bael are seasonal hard fruits belong to family Rutaceae. Both are native and common in the wild in dry plains of India and Sri Lanka. The therapeutic properties of wood apple and bael have been well documented ${ }^{14}$. These fruits are rich in vitamins and minerals, and can contribute significantly to the daily nutrient needs of the individual $^{31}$. Both trees are cultivated on a limited scale in Sri Lanka in domestic orchards. There is a considerable post harvest loss in both commodities in the chain of harvest to the final consumer. Nevertheless, processed products in the form of jam, squash and ready to serve beverages are available. However there is a need to diversify the product range to minimize post harvest losses.

Fruit juices have their best taste, aroma and colour when they are freshly extracted or expressed. All subsequent efforts to preserve them adversely affect their quality to varying degrees, depending upon the method of preservation employed ${ }^{7}$. In the current investigations an attempt has made to process wood apple and bael fruit to a fine reconstitutable powder. The processing conditions in spray drying technology are known to retain physical and chemical properties of processing material to a high degree. 
Spray drying technology originally developed to dehydrate milk and milk based products is currently being applied to process a broad spectrum of products beside dairy. Spray drying is a method for drying food liquids and some slurry in which the feed is mixed with heated air in a drying chamber. Rapid drying takes place and a dry powder is formed. Spray drying can accomplished with little loss in nutrients. Milk powders retain Vitamin A, Niacin riboflavin and other vitamins well'. Processing of products made from natural ingredients it is desirable to retain the natural properties and qualities in the final powder form. This is possible for some products, while others involve a recipe containing additional carriers, antioxidants, $\mathrm{pH}$-stabilizers and so forth.

There have been successful applications of spray drying technology to dehydrate fruit juices by spray drying in India, China and the products are available to consumers. Though the products are available, published data in respect to processing technologies are not available. Potential exits in Sri Lanka to evaluate possibilities of the application of spray drying technology to manufacture reconstitutable fruit juice powders in Sri Lanka.

\subsection{Objectives of the study}

1. Manufacture of spray dried powder from wood apple and bael with specific physical, chemical and functional properties.

2. Establishment of product identity reflecting the major chemical constituents and assessment of reconstitutability and organoleptic properties.

3. Studies on moisture sorption properties to predict the packaging needs. 
CHAPTER -2

\section{LITERATURE REVIEW}

